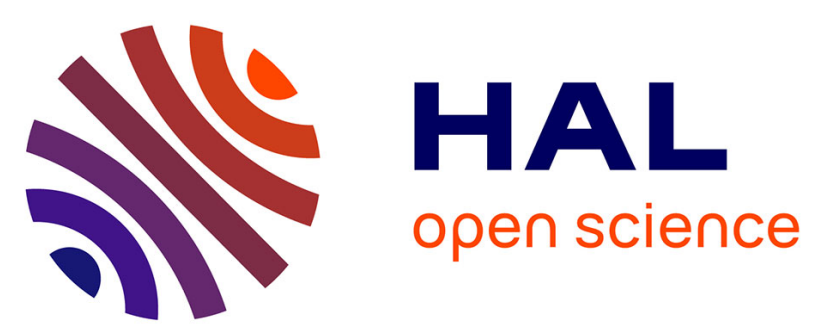

\title{
Dominance of Nosema ceranae in honey bees in the Balkan countries in the absence of symptoms of colony collapse disorder
}

Jevrosima Stevanovic, Zoran Stanimirovic, Elke Genersch, Sanja Kovacevic, Jovan Ljubenkovic, Milena Radakovic, Nevenka Aleksic

\section{To cite this version:}

Jevrosima Stevanovic, Zoran Stanimirovic, Elke Genersch, Sanja Kovacevic, Jovan Ljubenkovic, et al.. Dominance of Nosema ceranae in honey bees in the Balkan countries in the absence of symptoms of colony collapse disorder. Apidologie, 2011, 42 (1), pp.49-58. 10.1051/apido/2010034 . hal-01003566

\section{HAL Id: hal-01003566 https://hal.science/hal-01003566}

Submitted on 1 Jan 2011

HAL is a multi-disciplinary open access archive for the deposit and dissemination of scientific research documents, whether they are published or not. The documents may come from teaching and research institutions in France or abroad, or from public or private research centers.
L'archive ouverte pluridisciplinaire HAL, est destinée au dépôt et à la diffusion de documents scientifiques de niveau recherche, publiés ou non, émanant des établissements d'enseignement et de recherche français ou étrangers, des laboratoires publics ou privés. 


\title{
Dominance of Nosema ceranae in honey bees in the Balkan countries in the absence of symptoms of colony collapse disorder*
}

\author{
Jevrosima STEVANOVIC ${ }^{1}$, Zoran STANIMIROVIC ${ }^{1}$, Elke GENERSCH ${ }^{2}$, \\ Sanja R. Kovacevic ${ }^{1}$ Jovan LJUBEnKovic $^{1}$, Milena RADAKOvic ${ }^{1}$, Nevenka AleKSIC ${ }^{3}$ \\ ${ }^{1}$ Department of Biology, Faculty of Veterinary Medicine, University of Belgrade, Bul. oslobodjenja 18, \\ 11000 Belgrade, Serbia \\ ${ }^{2}$ Institute for Bee Research, Friedrich-Engels-Str. 32, 16540 Hohen Neuendorf, Germany \\ ${ }^{3}$ Department of Parasitic Diseases, Faculty of Veterinary Medicine, University of Belgrade, \\ Bul. oslobodjenja 18, 11000 Belgrade, Serbia
}

Received 27 October 2009 - Revised 16 February 2010 - Accepted 26 February 2010

\begin{abstract}
Nosema species were determined in honey bees from Balkan countries. A total of 273 Nosemapositive samples were analysed. Duplex PCR and PCR-RFLP with newly designed primers, nos-16S-fw/rv, were used to differentiate between N. apis and N. ceranae. N. apis was detected in only one sample (collected in 2008 in Serbia) and $N$. ceranae in all the others $(\mathrm{N}=272)$ including 35 older samples from Serbia collected between 2000 and 2005. No co-infection was detected. The results suggest (1) the dominance of $N$. ceranae infection in all Balkan countries monitored throughout the last three years; (2) the presence of N. ceranae in Serbia at least since 2000, which means that N. ceranae has not recently displaced N. apis; (3) the higher efficacy of PCR-RFLP with newly designed primers, nos-16S-fw/rv, in comparison with duplex PCR (100\%:82\%, respectively). The prevalence of $N$. ceranae in Balkan countries was not associated with an increase in nosemosis or colony losses resembling Colony Collapse Disorder (CCD).
\end{abstract}

\section{Nosema ceranae / PCR-RFLP / duplex PCR / Balkan countries}

\section{INTRODUCTION}

The European honey bee Apis mellifera was formerly considered parasitized with a single microsporidian species, Nosema apis Zander 1909. However, many recent reports show that another species of the same genus, $N$. ceranae Fries (Fries et al., 1996), infects A. mellifera almost worldwide (Huang et al., 2005, 2007; Higes et al., 2006; Fries et al., 2006; Klee et al., 2007; Paxton et al., 2007; Chauzat et al., 2007; Chen et al., 2008; Williams et al., 2008a; Invernizzi et al., 2009; Tapaszti et al., 2009; Giersch et al., 2009). Those reports also confirm that $N$. ceranae is not restricted to A. cer-

Corresponding author: J. Stevanovic, rocky@vet.bg.ac.rs

* Manuscript editor: Peter Rosenkranz ana in East Asia as it was originally considered (Fries et al., 1996; Fries, 1997). Recently, the presence of $N$. ceranae (Microsporidia) was detected even in North African honey bees (A. mellifera intermissa) (Higes et al., 2009a).

According to Klee et al. (2007), N. ceranae is an emergent pathogen of the European honey bee that most likely jumped from its host, the Asian honey bee A. cerana, to $A$. mellifera. Although it is still impossible to determine the exact time of the jump and transmission route of $N$. ceranae from A. cerana to A. mellifera, Klee et al. (2007) suggested that the process occurred most likely within the last decade, based on pure $N$. apis infection revealed in older (pre-2003) samples of A. mellifera. The same authors proposed that A. mellifera was formerly parasitized by $N$. 
apis alone and not $N$. ceranae and that $N$. ceranae, as an exotic parasite of A. mellifera, is displacing $N$. apis in A. mellifera populations. This view is supported by the results of Paxton et al. (2007) who found that $N$. ceranae has been present in Europe (Finland) since at least 1998, and that all Nosema infections in 2006 involved $N$. ceranae, either alone or with $N$. apis, meaning that $N$. ceranae has increased in frequency across this time period relative to $N$. apis. In the USA, Chen et al. (2008) found $N$. ceranae in A. mellifera as early as in 1995 and concluded that $N$. ceranae was not a new emerging pathogen of A. mellifera, but had transferred from $A$. cerana to A. mellifera earlier than Klee et al. (2007) previously recognized. In addition, there are indications of the presence of $N$. ceranae in Uruguay before 1990 (Invernizzi et al., 2009).

Several years ago, when incomprehensible colony losses occurred, $N$. ceranae was thought to be associated with the honey bee depopulation syndrome, lower honey production and increased mortality in colonies (symptoms resembling colony collapse disorder, CCD) detected throughout the year in central and southern Europe (Higes et al., 2005, 2006; Imdorf et al., 2006). It was shown that $N$. ceranae was highly virulent when experimentally inoculated into A. mellifera (Higes et al., 2007), but this study lacked any controls with $N$. apis. When the virulence of $N$. apis and $N$. ceranae was directly compared in cage experiment performed in 1994, the latter induced significantly higher mortality in comparison to the former (Paxton et al., 2007). According to Martín-Hernández et al. (2007), a significant causative association between the presence of $N$. ceranae and hive depopulation indicates that the colonization of $A$. mellifera by $N$. ceranae is related to bee losses accompanied by symptoms of CCD. Moreover, Higes et al. $(2008,2009 b)$ reported sudden collapses of bee colonies in field conditions as a result of $N$. ceranae infection. On the other hand, studies of Cox-Foster et al. (2007); vanEngelsdorp et al. (2009) and Johnson et al. (2009) did not confirm $N$. ceranae as the causal agent of CCD.

In Serbia and surrounding Balkan countries, N. apis was considered the only Nosema species that infects $A$. mellifera colonies, until Klee et al. (2007) revealed $N$. ceranae in honey bees in south Serbia in 2006. However, the prevalence and distribution of this species throughout Serbia is still obscure, and no data about Nosema species in honey bees are available for surrounding countries, Bosnia and Herzegovina, Montenegro and Former Yugoslav Republic of Macedonia (FYROM). According to the records of Veterinary Directorate, Ministry of Agriculture, Forestry and Water Management, Republic of Serbia (MAFWMRS) there were no significant changes in the incidence of nosemosis in Serbia in the last decade. However, lack of seasonality, a characteristic of nosemosis caused by N. ceranae (Martín-Hernández et al., 2007), was reported by beekeepers in the last threeyear time.

Today, molecular techniques are available that enable accurate differentiation between $N$. apis and $N$. ceranae: sequencing of the $16 \mathrm{~S}$ SSU rRNA gene (Fries et al., 1996), PCRRFLP of partial SSU rRNA (Klee et al., 2007), and duplex PCR using species-specific primer pairs (Martín-Hernández et al., 2007). The two latter methods were used in this study to reveal the species of Nosema prevalent in honey bees in Serbia, Bosnia and Herzegovina, Montenegro and FYROM in last three-year time (20062009) and to demonstrate whether or not $N$. ceranae displaced $N$. apis in these countries in the recent past. Furthermore, older samples collected between 2000 and 2005 from Serbia were analysed to reveal if $N$. ceranae is an emerging parasite that became prevalent in A. mellifera recently, or if A. mellifera has been harbouring $N$. ceranae for some time but was overlooked in routine microscopical diagnosis due to its morphological similarity with N. apis.

\section{MATERIALS AND METHODS}

\subsection{Samples, spore detection and DNA extraction}

A total of 325 honey bee samples were collected from Apis mellifera colonies located in four Balkan countries: Serbia $(\mathrm{N}=215)$, Bosnia and Herzegovina $(\mathrm{N}=45)$, Montenegro $(\mathrm{N}=28)$ and FYROM 
( $N=37$ ) in the years 2006-2009. Samplings were done in accordance with the guidelines of the Office International des Epizooties (OIE, 2008) by official person (Ivan Pavlovic, details given in Acknowledgements). Each sample was comprised of bees from the same hive (at least 60 adult forager bees collected from the hive entrance). Three to six hives were sampled per apiary/location. Sampling locations were picked depending on their geographic position with the aim of getting samples throughout the chosen Balkan countries. Bees were sampled in spring and summer (March-July). Hives were sampled irrespective of nosemosis and/or signs of other diseases; for each sampled colony it was recorded if the characteristics of CCD (sudden disappearance of adult bees prior to colony death, unattended brood, colony weakness, no dead or trembling bees around the hives) were observed at the time of sampling and in the years afterwards. In the final re-evaluation, updated CCD characteristics defined by vanEngelsdorp et al. (2009) were taken into consideration. Among the samples from Serbia 35 were older, collected between 2000 and 2005 (provided by veterinary institutes). These were collected in spring; the colonies from which these samples originated were categorised in the institutes' protocols as Nosema-positive with medium infection. No CCD symptoms were recognized after reviewing the records of the bee owners.

The samples were examined microscopically at $400 \times$ magnification for the presence of Nosema spores according to the guidelines of OIE (OIE, 2008). Only Nosema-positive samples $(\mathrm{N}=273)$ were used for DNA extraction (178 from Serbia, 38 from Bosnia and Herzegovina, 22 from Montenegro and 35 from FYROM). From each colony, abdomens of 60 adult bees were homogenized in a mortar with $60 \mathrm{~mL}$ of $\mathrm{ddH}_{2} \mathrm{O}$. In case of Nosemapositive samples, homogenates were filtered to remove coarse bee parts and obtained spore suspensions stored at $-20{ }^{\circ} \mathrm{C}$ until used for DNA extraction.

For DNA extraction, $1 \mathrm{~mL}$ of spore suspension was centrifuged (5 $\mathrm{min}, 16100 \mathrm{~g}$ ) and the supernatant discarded. Pellets were frozen in liquid nitrogen and crushed using sterile pellet pestles. DNA was extracted applying DNeasy Plant Mini Extraction Kit (Qiagen, Cat. No. 69104). The extracts were kept at $-20{ }^{\circ} \mathrm{C}$ until needed as DNA template in PCRs. Reference DNA extracts of N. apis and N. ceranae (kindly provided by Eva Forsgren, SLUUppsala, Sweden) confirmed to be positive by sequencing were used as the template for the posi- tive controls. Double-distilled water $\left(\mathrm{ddH}_{2} \mathrm{O}\right)$ was the template for the negative control.

\subsubsection{Identification of Nosema species with duplex PCR}

In duplex PCR, species-specific primers designed by Martín-Hernández et al. (2007) were used for differential diagnosis of $N$. apis and $N$. ceranae (321APIS-FOR/REV primers for detection of $N$. apis and 218MITOC-FOR/REV primers for detection of $N$. ceranae).

PCR conditions given by Martín-Hernández et al. (2007) were followed, with slight modifications. All PCRs were performed using a Mastercycler Personal (Eppendorf) in $25 \mu \mathrm{L}$ volumes containing $1 \times$ PCR-buffer A (Kapa Biosystems), $3 \mathrm{mM} \mathrm{MgCl}_{2}$ (Kapa Biosystems), $0.4 \mathrm{mM}$ of each deoxynucleoside triphosphate (Qiagen), $0.4 \mu \mathrm{M}$ of each primer (321APIS-FOR, 321APIS-REV, 218MITOC-FOR, 218MITOC-REV, made by Invitrogen, Carlsbad, CA), $0.2 \mathrm{mg} / \mathrm{mL}$ bovine serum albumin (New England Biolabs), 0.5 U of Taq polymerase (Kapa Biosystems) and $5 \mu \mathrm{L}$ of template DNA.

The thermocycler program consisted of $94{ }^{\circ} \mathrm{C}$ for $4 \mathrm{~min}$, followed by 10 cycles of $15 \mathrm{~s}$ at $94{ }^{\circ} \mathrm{C}$, $30 \mathrm{~s}$ at $61.8^{\circ} \mathrm{C}$, and $45 \mathrm{~s}$ at $72{ }^{\circ} \mathrm{C}, 20$ cycles of $15 \mathrm{~s}$ at $94{ }^{\circ} \mathrm{C}, 30 \mathrm{~s}$ at $61.8{ }^{\circ} \mathrm{C}$, and $50 \mathrm{~s}$ at $72{ }^{\circ} \mathrm{C}$ plus an additional $5 \mathrm{~s}$ of elongation for each successive cycle, and a final extension step at $72{ }^{\circ} \mathrm{C}$ for $7 \mathrm{~min}$. For each PCR, positive controls (reference $N$. apis and $N$. ceranae DNA extracts as template) and negative controls ( $\mathrm{ddH}_{2} \mathrm{O}$ as template) were run along with DNA extracts of isolates as template. PCR products ( $4 \mu \mathrm{L}$ of amplified DNA) were electrophoresed on $2 \%$ agarose gels $(1 \times \mathrm{TBE})$, stained with ethidium bromide, and visualised under UV light. A commercial O'RangeRuler ${ }^{\mathrm{TM}} 50$ bp DNA Ladder (Fermentas) was used as a size marker.

\subsubsection{Identification of Nosema species with PCR-RFLP}

A region of the 16S rRNA gene which is conserved for $N$. apis and $N$. ceranae (Klee et al., 2007) was selected for primer design using MacVector 6.5 (Oxford Molecular Ltd., Oxford, UK). Primers nos-16S-fw (5' - CGTAGACGCTATTCCCTAAGATT $-3^{\prime}$, positions 422 to 444 in U97150; Gatehouse and Malone, 1998) and 
nos-16S-rv (5' - CTCCCAACTATACAGTACACCTCATA -3', positions 884 to 909 in U97150, Gatehouse and Malone, 1998) were used to amplify ca. $488 \mathrm{bp}$ of partial 16S rRNA gene. All PCRs were performed using a Mastercycler Personal (Eppendorf) in $25 \mu \mathrm{L}$ volumes containing $1 \times$ PCR-buffer A (Kapa Biosystems), $2.5 \mathrm{mM} \mathrm{MgCl} 2$ (Kapa Biosystems), $0.2 \mathrm{mM}$ of each deoxynucleoside triphosphate (Qiagen), $0.5 \mu \mathrm{M}$ of each primer (nos-16S-fw, nos-16S-rv, made by Operon Biotechnologies, Inc., Huntsville, Al), $0.5 \mathrm{U}$ of Taq polymerase (Kapa Biosystems) and $5 \mu \mathrm{L}$ of template DNA.

The PCR parameters for amplification were: initial DNA denaturation of $4 \mathrm{~min}$ at $95{ }^{\circ} \mathrm{C}$ followed by 45 cycles of $1 \mathrm{~min}$ at $95{ }^{\circ} \mathrm{C}, 1 \mathrm{~min}$ at $53{ }^{\circ} \mathrm{C}$ and $1 \mathrm{~min}$ at $72{ }^{\circ} \mathrm{C}$, and terminated with a final extension step at $72{ }^{\circ} \mathrm{C}$ for $4 \mathrm{~min}$. For each PCR, positive controls (reference N. apis and N. ceranae DNA extracts as template) and negative controls ( $\mathrm{ddH}_{2} \mathrm{O}$ as template) were run along with DNA extracts of isolates as template. PCR products $(4 \mu \mathrm{L}$ of amplified DNA) were electrophoresed on $1.4 \%$ agarose gels $(1 \times \mathrm{TBE})$, stained with ethidium bromide, and visualised under UV light. A commercial O'RangeRuler ${ }^{\mathrm{TM}} 50$ bp DNA Ladder (Fermentas) was used as a size marker.

To differentiate between the species $N$. apis and $N$. ceranae, discriminating restriction endonuclease sites present in the PCR amplicon were used (Klee et al., 2007). The restriction endonuclease $\mathrm{Pac}$ I provides one unique digestion site for $N$. ceranae whilst the enzyme $N d e$ I only digests $N$. apis. Msp I digests $N$. apis and N. ceranae and is used as a control for successful restriction digestion of PCR products. The predicted restriction fragments produced from digestion of the PCR amplicons are $97 \mathrm{bp}, 118 \mathrm{bp}$, and $269 \mathrm{bp}$ for $N$. ceranae and, $91 \mathrm{~b}$, $131 \mathrm{bp}$ and 266 bp for N. apis (Fig. 1). PCR amplicons were digested with Msp I/Pac I and with Msp I/Nde I (New England Biolabs, NEB) in two reactions at $37{ }^{\circ} \mathrm{C}$ for $3 \mathrm{~h}$ to analyze and confirm the presence of each Nosema species in each sample. Digests were performed in $12.5 \mu \mathrm{L}$ volume with $10 \mu \mathrm{L}$ of the amplified DNA and 1.5 Units of each enzyme. The $1 \times$ NEBuffer 2 (provided by NEB with $M s p$ I) was used as buffer for the reactions. Msp I and Nde I show $100 \%$ activity with this buffer whilst Pac I performs to $75 \%$ in this buffer. Fragments were separated in a $3 \%$ NuSieve agarose gel (Cambrex Bio Science) in $1 \times$ TBE buffer with a $20 \mathrm{bp}$ ladder as size marker at $110 \mathrm{~V}$ for $1 \mathrm{~h} 30 \mathrm{~min}$. Gels were stained with ethidium bromide and visualised under UV light.

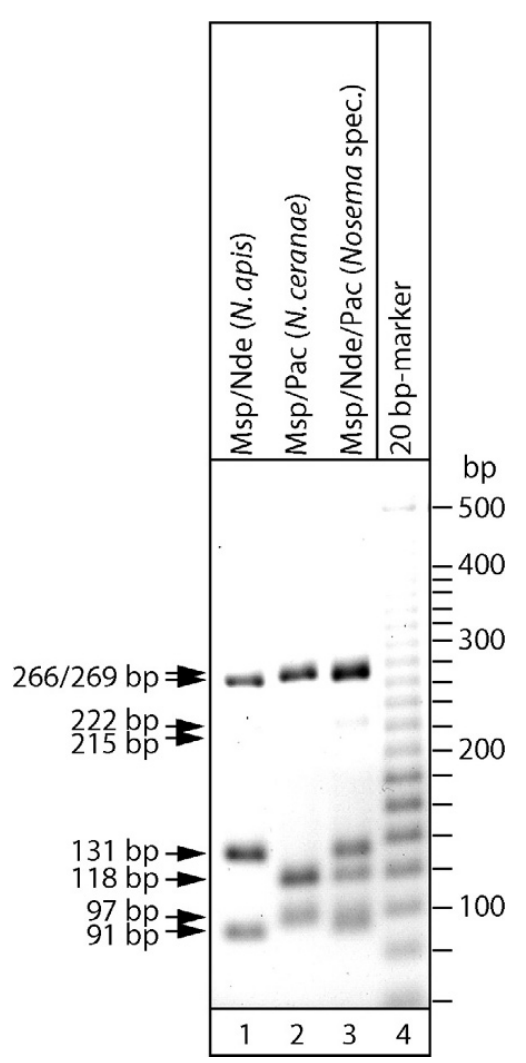

Figure 1. Restriction fragment length polymorphism (RFLP) of a 16S rRNA gene region conserved for $N$. apis and $N$. ceranae. A conserved region of the 16S rRNA gene of N. apis and N. ceranae was amplified by PCR. Subsequently, discriminating restriction endonuclease sites within this region were used to differentiate between the two Nosema species. Digestion by Msp I/Nde I results in three bands (91 bp, $131 \mathrm{bp}, 266 \mathrm{bp)}$ ) for $N$. apis (lane 1). Digestion by Msp I/Pac I results in three bands (97 bp, $118 \mathrm{bp}, 269 \mathrm{bp}$ ) for $N$. ceranae (lane 2). Weak bands of $222 \mathrm{bp}$ and $215 \mathrm{bp}$ represent incomplete digests by Nde I for N. apis and Pac I for N. ceranae, respectively. Mixed infections can also be identified using this method (lane 3).

\section{RESULTS}

By microscopic examination of collected bee samples $(\mathrm{N}=325) 273$ were found positive for Nosema sp. (84.0\%). In samples from Serbia, 178 (including all 35 older samples collected between 2000 and 2005) out of 215 examined, were Nosema-positive 
Table I. The results of differential diagnostic investigations of Nosema species in Apis mellifera throughout Serbia, Bosnia and Herzegovina, Montenegro and FYROM ${ }^{\mathrm{a}}$.

\begin{tabular}{ccccccc}
\hline Country & $\begin{array}{c}\text { No. of } \\
\text { collected } \\
\text { samples }\end{array}$ & $\begin{array}{c}\text { No. of } \\
\text { Noma-positive } \\
\text { samples }\end{array}$ & $\begin{array}{c}\text { Nosema-positive } \\
\text { samples }\end{array}$ & N. ceranae & N. apis & Co-infections \\
\hline Serbia & $215^{*}$ & $178^{*}$ & $82.8 \%$ & $177^{*}$ & 1 & $/$ \\
Bosnia and & 45 & 38 & $84.4 \%$ & 38 & $/$ & $/$ \\
Herzegovina & & 22 & $78.6 \%$ & 22 & $/$ & $/$ \\
Montenegro & 28 & 35 & $94.6 \%$ & 35 & $/$ & $/$ \\
FYROM & 37 & 273 & $84.0 \%$ & 272 & 1 & $/$ \\
Overall & 325 & & & & $/$ \\
\hline
\end{tabular}

${ }^{\text {a }}$ FYROM, Former Yugoslav Republic of Macedonia. * Including 35 historical samples.

$(82.8 \%)$. The percentage of Nosema-positive samples was $84.4 \%$ (38 infected out of 45 examined) among those from Bosnia and Herzegovina, $78.6 \%$ (22 infected out of 28) from Montenegro and 94.6\% (35 infected out of 37) from FYROM (Tab. I). Nosemapositive samples originated from apiaries scattered across the monitored countries (Fig. 2). All positive samples $(\mathrm{N}=273)$ underwent further analysis to identify the species of Nosema.

Duplex PCR with species-specific primers (321APIS-FOR/REV and 218MITOCFOR/REV) enabled differentiation between $N$. apis and $N$. ceranae in 224 samples out of 273 analysed (82\% successful amplifications), while 49 samples failed to produce a PCR product (18\%).

As expected, the PCR product of the reference $N$. apis sample with the primer pair 321APIS-FOR/REV was $321 \mathrm{bp}$, and the PCR product of reference $N$. ceranae sample with primer pair 218MITOC-FOR/REV was 218$219 \mathrm{bp}$. None of the two fragment lengths were present in the negative controls. Moreover, no co-infections were found. Among successfully amplified samples, 223 amplicons exibit a length of 218-219 bp which corresponds to $N$. ceranae, and only one sample (collected in the northernmost of Serbia in 2008) produced amplicon of $321 \mathrm{bp}$ in length corresponding to N. apis (Fig. 3).

All 273 samples (100\%) were successfully amplified with primers nos-16S-fw/rv and produced amplicons approximately $488 \mathrm{bp}$ in size (Fig. 4a). After digestion with the enzymes PacI, NdeI and MspI, RFLP patterns of 272

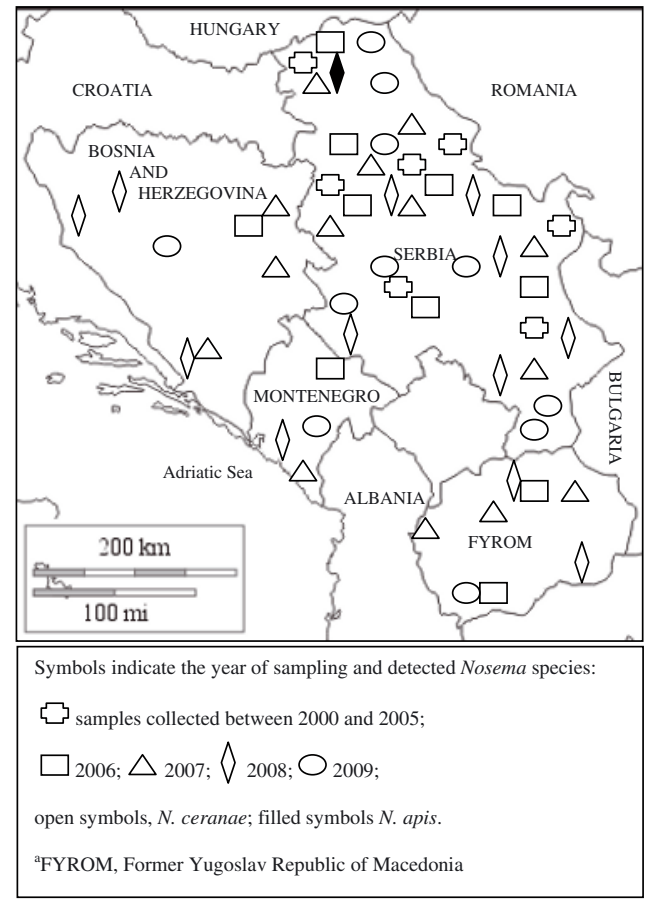

Figure 2. Map indicating sampling locations in Serbia, Bosnia and Herzegovina, Montenegro and FYROM $^{\mathrm{a}}$, and Nosema species distribution.

samples corresponded to that of $N$. ceranae control, and one sample matched the pattern of $N$. apis control (the same sample found to be $N$. apis in duplex PCR). No co-infections were found (Fig. 4b). The results of this study are summarized in Table I. 


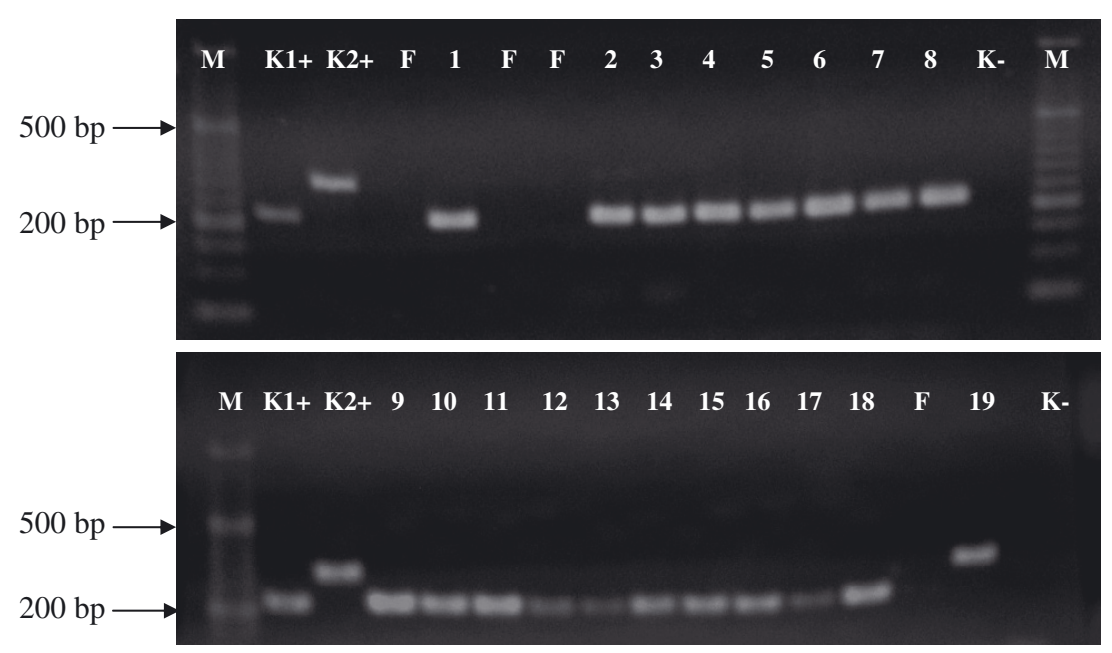

Figure 3. Ethidium bromide stained agarose gels showing the results of duplex PCR using primers 321APIS-FOR/REV and 218MITOC-FOR/REV. Lane M, 50 bp ladder; K1+, positive $N$. ceranae control; K2+, positive $N$. apis control; F, failed PCR; K-, negative control; 1-18, PCR products of samples that correspond to N. ceranae; 19 , PCR product of a single sample that correspond to N. apis.

Furthermore, no characteristics of CCD were observed in the colonies sampled in this study, either at the moment of sampling or at subsequent re-evaluation steps.

\section{DISCUSSION}

As in other geographic regions of Europe, $N$. apis was suspected as the single cause of nosemosis in A. mellifera colonies in Serbia and surrounding Balkan countries (Bosnia and Herzegovina, Montenegro and FYROM). The first report of $N$. ceranae in south Serbia (Klee et al., 2007) and the lack of data from surrounding Balkan countries indicated the need for differential diagnostic investigations of Nosema species in honey bees throughout Serbia, Bosnia and Herzegovina, Montenegro and FYROM. In addition, the recent reports of causative association between the presence of $N$. ceranae, bee losses (Martín-Hernández et al. 2007) and the sudden colony collapse of western honey bees due to $N$. ceranae (Higes et al., 2008, 2009b) justify such investigations.

The results of this study demonstrated $N$. ceranae in 272 samples and $N$. apis in only one sample which suggest the dominance of $N$. ceranae infection in all Balkan countries monitored throughout the last three years (20062009).

In this study, the presence and dominance of $N$. ceranae in A. mellifera in the territory of Bosnia and Herzegovina, Montenegro and FYROM in the period from 2006-2009 is first reported. No $N$. apis or mixed $N$. apis/N. ceranae-infections were detected in samples from these countries. These results indicate that $N$. ceranae did not displace $N$. apis in these countries in the recent past, but any discussion about the time when the replacement took place is a matter of speculation due to the absence of samples taken prior to 2006 originating from these Balkan countries.

The detection solely of $N$. ceranae in older samples collected between 2000 and 2005 from Serbia indicates that this species has been present in Serbia since at least 2000, but remained undetected since molecular techniques that enable differential diagnosis of $N$. apis and $N$. ceranae were not available at that time. The finding of $N$. ceranae in older samples (from 2000 onwards) revealed that this parasite may have caused the infection in honey bees in Serbia earlier than it had been previously recognized by Klee et al. (2007). N. apis was 

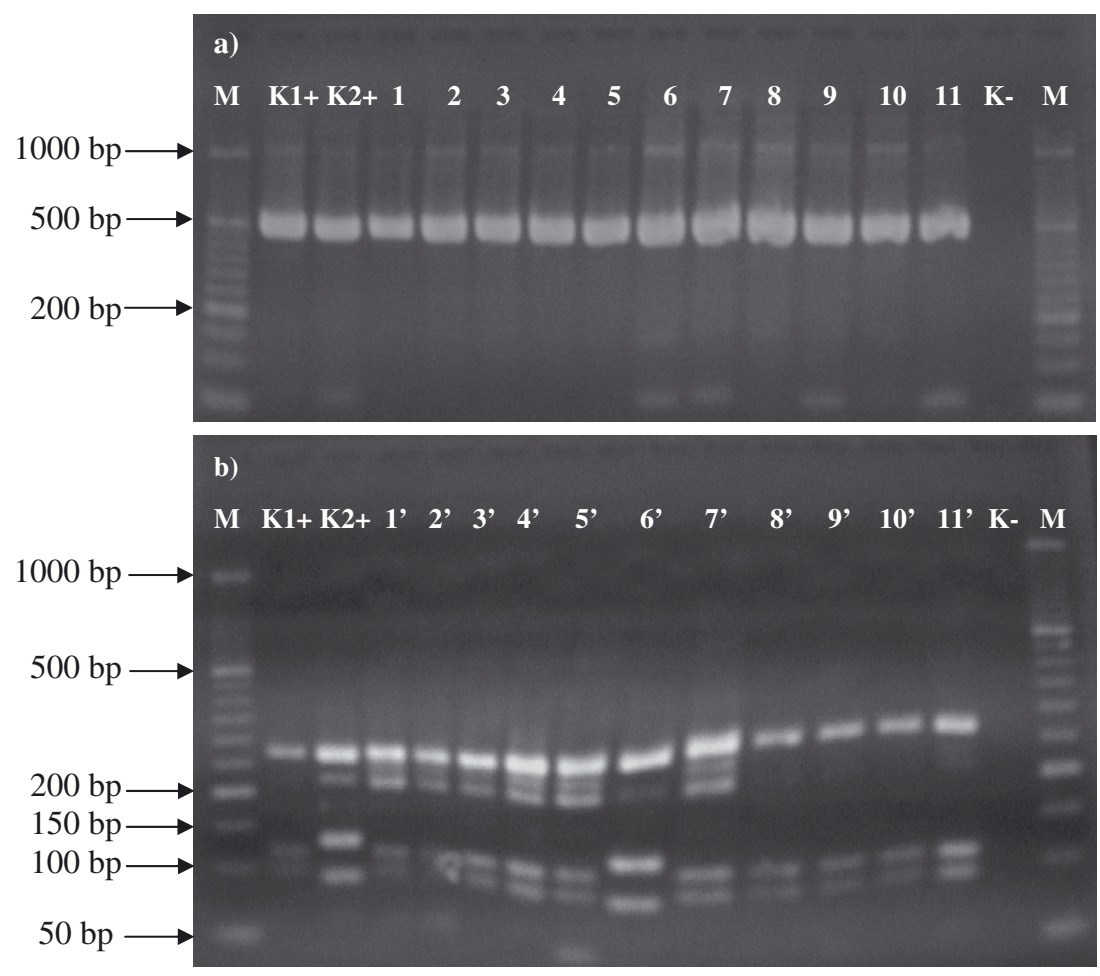

Figure 4. Ethidium bromide stained agarose gels showing the results of PCR-RFLP. a) 1-11, PCR products using primers nos-16S-fw/rv; Lane M, 50 bp ladder; K1+, positive $N$. ceranae control; K2+, positive $N$. apis control; K-, negative control. b) RFLP products after digestion with the enzymes MspI, PacI and NdeI. Lane M, 50 bp ladder; $\mathrm{K} 1+$, positive $N$. ceranae control; $\mathrm{K} 2+$, positive $N$. apis control; K-, negative control; $1^{\prime}-5^{\prime}$ and $7^{\prime}-11^{\prime}$, RFLP of samples that correspond to $N$. ceranae; $6^{\prime}$, RFLP of a single sample that correspond to N. apis.

not found in any of older samples collected between 2000 and 2005. In the samples collected in the period 2006-2009, N. apis was detected in only one sample (collected from the northernmost of Serbia in 2008). Although most honey bee colonies and individual bees may be co-infected with both microsporidian species, $N$. apis and $N$. ceranae (Klee et al., 2007; Paxton et al., 2007), no co-infections were found in our study, similarly to the findings of Huang et al. (2008) in Taiwan and Martinique. Such results question whether or not $N$. apis was ever prevalent in Balkan countries. The impressive dominance of $N$. ceranae confirmed by analysing a considerable number of samples in this study, including older samples collected between 2000 and 2005, as well as the absence of any molecular evidence of $N$. apis as a predominant honey bee microsporidian in Serbia, may indicate that $N$. ceranae is not an emergent pathogen of honey bees in Serbia, at least it was not in the last 10 years. This is congruent with the data of MAFWMRS that state that the incidence of nosemosis has not changed throughout the last 10 years, although lack of seasonality, characteristic for $N$. ceranae (Martín-Hernández et al., 2007), was reported by beekeepers in the last three years. As the symptoms of CCD were not observed in the apiaries sampled in this study, the association between $N$. ceranae and CCD cannot be affirmed, which coincides with the most recent findings of vanEngelsdorp et al. (2009) and Johnson et al. (2009).

In all the Balkan countries monitored, the usage of fumagillin for the control of 
nosemosis has been common and extensive, despite the fact that if not used properly it can have harmful effects on human health (Stanimirovic et al., 2006, 2007; Stevanovic et al., 2006, 2008). However, future studies are necessary to reveal if fumagillin could have played a role in the displacement of $N$. apis with $N$. ceranae, since its efficacy against both parasite species has been proven, but without simultaneous comparative investigations (Williams et al., 2008b).

The identification of Nosema species in this study was done using two methods: duplex PCR according to Martín-Hernández et al. (2007) and PCR-RFLP deploying the primers nos- $16 \mathrm{~S}-\mathrm{fw} / \mathrm{rv}$. The efficacy in achieving the final results was $82 \%$ over $100 \%$ in favour of PCR-RFLP. Although PCR-RFLP is more time-consuming and more expensive than duplex-PCR detection, PCR-RFLP should be the method of choice if $100 \%$ accurate results are needed.

The subspecies of A. mellifera and the duration of exposure to the pathogen were suggested as factors that may affect the virulence of $N$. ceranae (Invernizzi et al., 2009). In the present study there were two southeastern European subspecies, A. m. carnica and A. $m$. macedonica, which both belong to the $\mathrm{C} 2 \mathrm{D}$ and C2E mtDNA haplotype (Susnik et al., 2004; Kozmus et al., 2007) of the C Mediterranean lineage (Garnery et al., 1992; Franck et al., 2000; Meixner et al., 2007). Indigenous non-hybridized $A$. $m$. carnica populations in the region (Stanimirovic et al., 2005; Sušnik et al., 2004; Kozmus et al., 2007), an important genetic resource for future bee breeding programs (Stanimirovic et al., 2005; De la Rua, 2009), may be more resistant to $N$. ceranae. Nevertheless, the influence of bee subspecies on their susceptibility could be the subject of further investigation. Finally, there may be distinctions in the virulence of the haplotypes of $N$. ceranae (Williams et al., 2008a, b) similarly to the genotype-specific ones of Paenibacillus larvae (Genersch et al., 2005, 2006; Ashiralieva and Genersch, 2006). Thus, if the bees from two distant European regions harbor different $N$. ceranae haplotypes, a different outcome of $N$. ceranae infection can be easily comprehensible.

\section{ACKNOWLEDGEMENTS}

This study was supported by the Ministry of Science and Technological Development of the Republic of Serbia (Grant No. 143022). We are grateful to Dr. Eva Forsgren (Department of Ecology, Swedish University of Agricultural Sciences, Uppsala, Sweden) for providing reference DNA extracts of $N$. apis and N. ceranae used as positive controls in this study. We thank Dr. Med. Rodoljub Zivadinovic (the President of the Serbian Federation of Beekeeping Organization), Budimir Plavsic, DVM, MSc (the Head of the Section of Animal Health Protection and Welfare, Veterinary Directorate, Ministry of Agriculture, Forestry and Water Management, Republic of Serbia). We are grateful to Ivan Pavlovic, DVM, PhD (The Scientific Veterinary Institute of Serbia, Belgrade), Mira Zivadinovic, DVM, vet. spec. (Veterinary Institute, Sombor), Zoran Raicevic (Veterinary Institute, Nis) for providing older samples collected between 2000 and 2005, and the beekeepers who allowed access to their colonies. Samplings were done by Ivan Pavlovic, DVM, PhD, Research Fellow, The Scientific Veterinary Institute of Serbia, Belgrade, license No. 1864.

Dominance de Nosema ceranae chez les abeilles des pays balkaniques en l'absence de symptômes du syndrome d'effondrement des colonies.

Nosema ceranae / PCR-RFLP / PCR duplex / pays des Balkans / abeilles

\footnotetext{
Zusammenfassung - Nosema ceranae dominiert in den Honigbienenvölkern auf dem Balkan in Abwesenheit von Symptomen von, colony collapse disorder' (CCD). Honigbienenvölker (Apis mellifera) wurden in Serbien, BosnienHerzegowina, Montenegro und der Ehemaligen jugoslawischen Republik Mazedonien (Former Yugoslav Republic of Macedonia, FYROM) zwischen 2006 und 2009 beprobt, um zu untersuchen, ob und mit welcher Nosema-Spezies diese Völker in den letzten drei Jahren infiziert waren. Zusätzlich wurden Nosema-positive Bienenproben aus Serbien aus dem Zeitraum 2000-2005 untersucht, um die Frage zu beantworten, ob $N$. ceranae entweder ein neuer Krankheitserreger ist, der erst seit kurzem A. mellifera infiziert, oder schon seit längerer Zeit in den untersuchten Ländern bei A. mellifera vorkommt. Zur Differenzierung von $N$. apis und $N$. ceranae wurden zwei verschiedene molekulare Methoden eingesetzt: Duplex-PCR-Analysen unter der Verwendung Spezies-spezifischer Primer sowie PCR-RFLP-Analysen, die mit hier erstmals veröffentlichten Primern (nos-16S-fw/rv; Abb. 1)
} 
durchgeführt wurden. Insgesamt wurden 273 Nosema-positive Proben $(\mathrm{N}=178,38,22$ und 35 jeweils aus Serbien, Bosnien-Herzegowina, Montenegro und Mazedonien) untersucht. In nur einer Probe wurde N. apis nachgewiesen, während in allen anderen Proben $(\mathrm{N}=272)$ einschließlich der älteren Proben aus Serbien, die aus dem Zeitraum 2000-2005 stammten, nur $N$. ceranae nachgewiesen werden konnte (Tab. I, Abb. 2-4). Mischinfektionen wurden nicht gefunden. Diese Ergebnisse zeigen, (1) dass $N$. ceranae-Infektionen in den genannten Balkanstaaten in den letzten drei Jahren klar dominierten, und (2) dass $N$. ceranae in Serbien mindestens seit dem Jahr 2000 vorkommt und hier nicht erst kürzlich $N$. apis in der Honigbienenpopulation verdrängt hat. Darüber hinaus zeigte der Methodenvergleich, dass die PCR-RFLP-Analysen mit den neuen Primern nos-16S-fw/rv im Vergleich zur Duplex-PCR genauere Ergebnisse liefern (100\% gegenüber $82 \%$ korrekt positive Ergebnisse). Ein wichtiges Ergebnis dieser Studie ist auch, dass das Vorkommen von $N$. ceranae in den untersuchten Ländern nicht einherging mit einem Anstieg an Nosemosis oder mit Völkerverlusten, die von ,colony collapse disorder"-ähnlichen (CCD-ähnlichen) Symptomen begleitet waren.

\section{Nosema ceranae / PCR-RFLP / Duplex-PCR / Balkanstaaten}

\section{REFERENCES}

Ashiralieva A., Genersch E. (2006) Reclassification, genotypes and virulence of Paenibacillus larvae, the etiological agent of American foulbrood in honeybees - a review, Apidologie 37, 411-420.

Chauzat M.P., Higes M., Martín-Hernández R., Meana A., Cougoule N., Faucon J.P. (2007) Presence of Nosema ceranae in French honeybee colonies, J. Apic. Res. 46, 127-128.

Chen Y., Evans J.D., Smith I.B., Pettis J.S. (2008) Nosema ceranae is a long-present and widespread microsporidean infection of the European honey bee (Apis mellifera) in the United States, J. Invertebr. Pathol. 97, 186-188.

Cox-Foster D.L., Conlan S., Holmes E.C., Palacios G., Evans J.D., Moran N.A., Quan P.L., Briese T., Hornig M., Geiser D.M., Martinson V., vanEngelsdorp D., Kalkstein A.L., Drysdale A., Hui J., Zhai J.H., Cui L.W., Hutchison S.K., Simons J.F., Egholm M., Pettis J.S., Lipkin W.I. (2007) A metagenomic survey of microbes in honey bee colony collapse disorder, Science 318 , 283-287.

De la Rúa P., Jaffé R., Dall’Olio R., Muñoz I., Serrano J. (2009) Biodiversity, conservation and current threats to European honeybees, Apidologie 40, 263-284.
Franck P., Garnery L., Solignac M., Cornuet J.M. (2000) Molecular confirmation of a fourth lineage in honey bees from the Near East, Apidologie 31, 167-180.

Fries I. (1997) Protozoa, in: Morse R.A., Flottum K. (Eds.), Honey bee pests, predators and diseases, 3rd ed., A.I. Root Company, Medina, Ohio, USA, pp. 59-76.

Fries I., Feng F., da Silva A., Slemenda S.B., Pieniazek J. (1996) Nosema ceranae n. sp. (Microspora, Nosematidae), morphological and molecular characterization of a microsporidian parasite of the Asian honey bee Apis cerana (Hymenoptera, Apidae), Eur. J. Protistol. 32, 356-365.

Fries I., Martín R., Meana A., García-Palencia P., Higes M. (2006) Natural infections of Nosema ceranae in European honey bees, J. Apic. Res. 45, 230-233.

Garnery L., Cornuet J.M., Solignac M. (1992) Evolutionary History of the Honey Bee Apis mellifera Inferred from Mitochondrial DNA Analysis, Mol. Ecol. 1, 145-154.

Gatehouse H.S., Malone L.A. (1998) The ribosomal RNA gene region of Nosema apis (Microspora): DNA sequence for small and large subunit rRNA genes and evidence of a large tandem repeat unit size, J. Invertebr. Pathol. 71, 97-105.

Genersch E., Ashiralieva A., Fries I. (2005) Strainand genotype-specific differences in virulence of Paenibacillus larvae subsp. larvae, a bacterial pathogen causing American foulbrood disease in honeybees, Appl. Environ. Microbiol. 71, 75517555 .

Genersch E., Forsgren E., Pentikäinen J., Ashiralieva A., Rauch S., Kilwinski J., Fries I. (2006) Reclassification of Paenibacillus larvae subsp. pulvifaciens and Paenibacillus larvae subsp. larvae as Paenibacillus larvae without subspecies classification, Int. J. Syst. Evol. Microbiol. 56, 501-511.

Giersch T., Berg T., Galea F., Hornitzky M. (2009) Nosema ceranae infects honey bees (Apis mellifera) and contaminates honey in Australia, Apidologie 40, 117-123.

Higes M., García-Palencia P., Martín-Hernández R., Meana A. (2007) Experimental infection of Apis mellifera honeybees with Nosema ceranae (Microsporidia), J. Invertebr. Pathol. 94, 211-217.

Higes M., Martín R., Meana A. (2006) Nosema ceranae, a new microsporidian parasite in honeybees in Europe, J. Invertebr. Pathol. 92, 93-95.

Higes M., Martín R., Sanz A., Álvarez N., Sanz A., García-Palencia P., Meana A. (2005) El síndrome de despoblamiento de las colmenas en España. Consideraciones sobre su origen, Vida Apícola 133, 15-21.

Higes M., Martín-Hernández R., Botías C., GarridoBailón E., González-Porto A.V., Barrios L., Del Nozal M.J., Bernal J.L., Jiménez J.J., GarcíaPalencia P., Meana A. (2008) How natural 
infection by Nosema ceranae causes honeybee colony collapse, Environ. Microbiol. 10, 26592669.

Higes M., Martín-Hernández R., Garrido-Bailón E., Botías C., Meana A. (2009a) The presence of Nosema ceranae (Microsporidia) in North African honey bees (Apis mellifera intermissa), J. Apic. Res. 48, 217-219.

Higes M., Martín-Hernández R., Garrido-Bailón E., González-Porto A.V., García-Palencia P., Meana A., del Nozal M.J., Mayo R., Bernal J.L. (2009b) Honeybee colony collapse due to Nosema ceranae in professional apiaries, Environ. Microbiol. Rep. $1,110-113$.

Huang W.F., Jiang J.H., Chen Y.W., Wang C.H. (2005) Complete rRNA sequence of the Nosema ceranae from honeybee (Apis mellifera), https://gra103. aca.ntu.edu.tw/gdoc/F90632004a.pdf.

Huang W.F., Bocquet M., Lee KC, Sung I.H., Jiang J.H., Chen Y.W., Wang C.H. (2008) The comparison of rDNA spacer regions of Nosema ceranae isolates from different hosts and locations, J. Invertebr. Pathol. 97, 9-13.

Huang W.F., Jiang J.H., Chen Y.W., Wang C.H. (2007) A Nosema ceranae isolate from the honeybee Apis mellifera, Apidologie 38, 30-37.

Imdorf A., Charrière J.D., Gallmann P. (2006) Mögliche Ursachen für die Völkerverluste der letzten Jahre, Schweiz. Bienenztg. 129, 6-10.

Invernizzi C., Abud C., Tomasco I.H., Harriet J., Ramallo G., Campá J., Katz H., Gardiol G., Mendoza Y. (2009) Presence of Nosema ceranae in honeybees (Apis mellifera) in Uruguay, J. Invertebr. Pathol. 101, 150-153.

Johnson R.M., Evans J.D., Robinson G.E., Berenbaum M.R. (2009) Changes in transcript abundance relating to colony collapse disorder in honey bees (Apis mellifera), PNAS 106, 14790-14795.

Klee J., Besana A.M., Genersch E., Gisder S., Nanetti A., Tam D.Q., Chinh T.X., Puerta F., Ruz J.M., Kryger P., Message D., Hatjina F., Korpela S., Fries I., Paxton R.J. (2007) Widespread dispersal of the microsporidian Nosema ceranae, an emergent pathogen of the western honey bee, Apis mellifera, J. Invertebr. Pathol. 96, 1-10.

Kozmus P., Stevanovic J., Stanimirovic Z., Stojic V., Kulisic Z., Meglic V. (2007) Analysis of mitochondrial DNA in honey bees (Apis mellifera) from Serbia, Acta Vet.-Beograd 57, 465-476.

Martín-Hernández R., Meana A., Prieto L., Martínez Salvador A., Garrido-Bailón E., Higes M. (2007) Outcome of colonization of Apis mellifera by Nosema ceranae, Appl. Environ. Microbiol. 73, 6331-6338.

Meixner M.D., Worobik M., Wilde J., Fuchs S., Koeniger N. (2007) Apis mellifera mellifera in eastern Europe - morphometric variation and determination of its range limits, Apidologie 38, 191-197.

OIE (2008) Manual of Diagnostic Tests and Vaccines for Terrestrial Animals, Chap. 2.2.4., Nosemosis of Honey Bees, http://www.oie.int/fr/normes/ mmanual/2008/pdf/2.02.04_NOSEMOSIS.pdf.

Paxton R.J., Klee J., Korpela S., Fries I. (2007) Nosema ceranae has infected Apis mellifera in Europe since at least 1998 and may be more virulent than Nosema apis, Apidologie 38, 558-565.

Stanimirovic Z., Stevanovic J., Andjelkovic M. (2005) Chromosomal diversity in Apis mellifera carnica from Serbia, Apidologie 36, 31-42.

Stanimirovic Z., Stevanovic J., Bajic V., Radovic I. (2007) Evaluation of genotoxic effects of fumagillin (dicyclohexylamine) by citogenetic tests in vivo, Mutat. Res. 628, 1-10.

Stanimirovic Z., Stevanovic J., Kulic M., Stojic V. (2006) Frequency of chromosomal aberrations in the evaluation of genotoxic potential of dicyclohexylamine (fumagillin) in vivo, Acta Vet.Beograd 56, 353-366.

Stevanovic J., Stanimirovic Z., Pejin I.I., Lazarevic M. (2006) Monitoring of mitotic index and frequency of micronuclei in evaluation of genotoxic potential of fumagillin (dicyclohexylamine) in vivo, Acta Vet.-Beograd 56, 437-448.

Stevanovic J., Stanimirovic Z., Radakovic M., Stojic V. (2008) In vitro evaluation of the clastogenicity of fumagillin, Environ. Mol. Mutagen. 49, 594-601.

Sušnik S., Kozmus P., Poklukar J., Megliè V. (2004) Molecular characterisation of indigenous Apis mellifera carnica in Slovenia, Apidologie 35, 623636.

Tapaszti Z., Forgách P., Kovágó C., Békési L., Bakonyi T., Rusvai M. (2009) First detection and dominance of Nosema ceranae in Hungarian honeybee colonies, Acta Vet. Hung. 57, 383-388.

vanEngelsdorp D., Evans J.D., Saegerman C., Mullin C., Haubruge E., Nguyen B.K., Frazier M., Frazier J., Cox-Foster D., Chen Y., Underwood R., Tarpy D.R., Pettis J.S. (2009) Colony collapse disorder: a descriptive study, PLoS One 4, e6481.

Williams G.R., Shafer A.B.A., Rogers R.E.L., Shutler D., Stewart D.T. (2008a) First detection of Nosema ceranae, a microsporidean parasite of European honey bees (Apis mellifera), in Canada and central USA, J. Invertebr. Pathol. 97, 189-192.

Williams G.R., Sampson MA, Shutler D., Rogers R.E.L. (2008b) Does fumagillin control the recently detected invasive parasite Nosema ceranae in western honey bees (Apis mellifera)? J. Invertebr. Pathol. 99, 342-344.

Zander E. (1909) Tierische Parasiten als Krankheitserreger bei der Biene, Münchener Bienenzeitung 31, 196-204. 